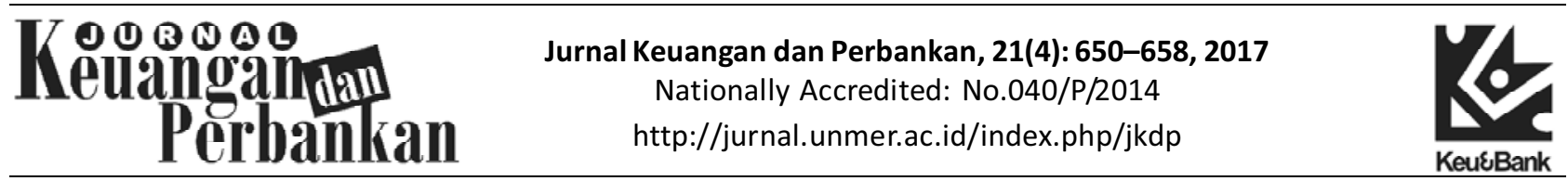

\title{
The Determinants of the Credit Quality Decision on Retail Consumer
}

\author{
Suwinto Johan \\ Department of Management Wiyatamandala School of Business Jakarta \\ Jl. Senen Raya 135 Jakarta, 10410, Indonesia
}

\begin{tabular}{|c|c|}
\hline & ABSTRACT \\
\hline \multirow{6}{*}{$\begin{array}{l}\text { Keywords: } \\
\text { Credit Quality; } \\
\text { Consumer } \\
\text { Behavior; Financ- } \\
\text { ing Institution; } \\
\text { Retail Consumer; } \\
\text { 4C Analysis }\end{array}$} & The aim of this study was to study the retail customers' $4 \mathrm{C}$ (character, capacity, collateral, \\
\hline & and capital) that affected credit quality on finance companies. This study focused on the \\
\hline & financing of used motorcycles from 2013-2014 with the position of balanced of book per \\
\hline & December 2015. This study used artificial intelligence concept with scoring system. The \\
\hline & $\begin{array}{l}\text { dependent variable was the customer credit quality that was overdue } 90 \text { days, and the } \\
\text { independent variables were character, capacity, collateral and capital of the customers. }\end{array}$ \\
\hline & $\begin{array}{l}\text { This study took samples of } 67,500 \text { customers using logistic regression test model. The } \\
\text { empirical results showed that } 4 \mathrm{C} \text { had a significant effect on credit quality. There were } 12\end{array}$ \\
\hline \multirow{4}{*}{$\begin{array}{l}\text { JEL Classification: } \\
\text { G23, G32 }\end{array}$} & out of 13 variables that showed significant influence namely sex, age, length of stay, \\
\hline & home ownership, marital status, employment status, cost ratio, motor guarantee brand, \\
\hline & $\begin{array}{l}\text { ownership status, down payment, and tenor. This significance was tested with a } 5 \text { per- } \\
\text { cent confidence level. Income did not have significant effect. }\end{array}$ \\
\hline & ABSTRAK \\
\hline \multirow{11}{*}{$\begin{array}{l}\text { Kata Kunci: } \\
\text { Kualitas Kredit; } \\
\text { Perilaku Konsumen; } \\
\text { Lembaga } \\
\text { Pembiayaan; } \\
\text { Konsumen Ritel; } \\
\text { Analisis 4C }\end{array}$} & Tujuan penelitian ini adalah untuk mengetahui 4C (character, capacity, collateral, dan capital) \\
\hline & konsumen retail yang mempengaruhi kualitas kredit pada perusahaan pembiayaan. Penelitian ini \\
\hline & menfokuskan pada pembiayaan sepeda motor bekas dari tahun 2013-2014 dengan posisi tutup \\
\hline & buku per Desember 2015. Penelitian ini mempergunakan konsep artificial intelligence dengan \\
\hline & scoring sistem. Variabel dependen adalah kualitas kredit konsumen yang telah overdue 90 hari \\
\hline & dan variabel independen adalah karakter, kapasitas, barang jaminan dan modal daripada \\
\hline & konsumen. Penelitian ini mengambil sampel sebesar 67.500 konsumen dengan model uji regresi \\
\hline & logistic. Hasil empiris menunjukkan bahwa $4 \mathrm{C}$ memiliki pengaruh yang signifikan terhadap \\
\hline & kualitas kredit. Terdapat 12 dari 13 variabel yang menunjukkan pengaruh yang signifikan yakni \\
\hline & $\begin{array}{l}\text { jenis kelamin, umur, lama tinggal, kepemilikan rumah, status nikah, status pekerjaan, rasio biaya, } \\
\text { merek motor jaminan, status kepemilikan, uang muka, dan tenor. Signifikan ini diuji dengan }\end{array}$ \\
\hline & tingkat keyakinan 5\%. Untuk pendapatan tidak memiliki pengaruh yang signifikan. \\
\hline
\end{tabular}

Corresponding Author:

Suwinto Johan: Telp. +6221348322350

ISSN:2443-2687 (Online)

E-mail: suwintojohan@gmail.com

ISSN:1410-8089 (Print) 
One of the main functions of financial institutions, particularly financing companies, is to deal with risks. One of the crucial risks is credit risk. Credit risk is the main risk of business in the finance distribution and giving. Credit risk represents the risk of the customer's ability to repay the principal and interest borrowing obligations on the loan received or credit received. Financing companies that are able to handle credit risk well will have good financial performance. Credit risk begins with the selection of customers who will be given financing or credit. After financing is given, the process of handling customers becomes important.

The higher the credit risk is, the better the performance of financial institutions is. All financial institutions will look for a good process in giving credit by studying costumer behavior in the early stage. At this time, some financial institutions and companies begin to use artificial intelligence and big data in selecting costumers.

The financing company will study the consumer behavior with bad financing as well as smooth financing by using scoring and big data. Artificial Intelligence is used by giving score or value to every aspect of costumer which is considered to have an effect on credit quality. From this scoring, the financing company finds the determinant of nonperforming loan. The determinant is associated with the principal in the provision of credit namely 5C (character, conditions, capacity, collateral, and capital). By using artificial intelligence, this scoring makes financing companies easier to conduct credit assessments. Artificial intelligence will give a score or a certain value on certain aspects to customers who will get credit. The finance company will determine the limits on credit by granting categories approved, rejected, and considered.

Credit scoring has been used by many financial institutions. The use of credit scoring has increased the efficiency of financial institutions. Credit scoring is implemented with several non- parametric methods, including regression logistics, quadratic discriminant analysis (QDA), and others (Blanco et al., 2013).

Credit scoring is developed to improve the quality of banking credit and increase the objectivity of credit decisions. Credit scoring will be able to provide recommendations for good credit and bad credit. A good credit is the one that is able to repay the loan distributed. Credit quality determination is based on historical data of customer behavior that has occurred (Bee, Ismail, \& Simon, 2011).

Devaney \& Lytton (1995) found that the use of credit scoring is able to predict the rate of insolvency, risk of insolvency, and ability to pay debt of banking customers. This study investigated 5 variables namely family status, employment status, personal information, financial data, and bureau credit information.

The context of 5C concepts are character, conditions, capacity, collateral, and capital. Each determinant is proxied with variables of the costumers. 5C is described as follows: (1) character is the nature of the potential consumers to be given credit. This factor becomes an important factor to know costumer's desire in fulfilling the obligation; (2) capacity is the financial capability of prospective customers in obtaining income and paying back their obligations. The use of this factor is to measure potential customers' ability to repay their obligations in a timely manner from the business or income earned; (3) capital is the amount of capital owned or inculcated by prospective customer. This capital is usually measured by the amount of down payment or the difference between the collateral and the loan value/financing. This difference is self-capital of the prospective customer that is not from the loan value; (4) collateral is goods that will be guaranteed to the financing company. The financing company uses the collateral as a source of loan repayment if the prospective customer is unable to repay the loan; and (5) condi- 


\section{Jurnal Keuangan dan Perbankan | PERBANKAN}

Vol. 21, No. 4, Oktober 2017: 650-658

tion of economy is the external or macro factors that affect the condition of prospective customers in returning their obligations.

The financing company will analyze $5 \mathrm{C}$ of prospective customers before providing financing. The financing company conducts a survey/interview with the prospective customer, stakeholders of prospective customers and other sources to gain a description of $5 \mathrm{C}$ of the prospective customer. This verification process depends on the employee's ability and the available data source. If all information reflects good 5C, then the financing will be given.

If the customer does not meet the obligation to pay the installment due, then the finance company will face bad or stuck credit. If this bad credit rises, the financial risk of financing companies will be disrupted. As a result financing companies will experience liquidity problems that can lead to financial distress.

Financial Services Authority (OJK) through POJK No.29/2014 provides the following categories of financing receivables: (1) smooth or fluent if there is no delay or there is a delay in payment of principal and/or interest up to 30 calendar days; (2) in particular attention if there is any delay in payment of principal and/ or interest that has exceeded 30 calendar days up to 90 calendar days; (3) less fluent if there is any delay in payment of principal and/or interest that has exceeded $90 \mathrm{cal}-$ endar days up to 120 calendar days; (4) doubtful if there is any delay in payment of principal and/ or interest that has exceeded 120 calendar days up to 180 calendar days; or (5) bad or stuck if there is any delay in payment of principal and/ or interest that has exceeded 180 calendar days.

This study is unique by analyzing the determinants of bad or stuck credit by using artificial intelligence on financing companies with a special portfolio of used motorcycle customer financing from 2013-2014. This study limits by examining only $4 \mathrm{C}$ outside the conditions or macroeconomic parameters. Conditions are external factors of the customers and financing companies. Some kinds of similar researches that have been done are by Rokhim \& Yanti (2014), Usman, Kamaludin, \& Darmansyah (2015), Aryani (2016), Sutanto \& Hamdani (2016), Ronny (2016), and others.

Sutanto \& Hamdani (2016) conducted a study of 100 customers in Bank Jateng and found that income, family size, gender, and occupation had significant influence on the individual credit at PT. Bank Jateng while the respondent age did not have a significant effect on individual credit at PT. Bank Jateng. The study used linear regression.

Aryani (2016) investigated the determinants of internal factors of banking and macroeconomic conditions towards Non Performing Financing in syariah banking in Indonesia. This research used 7 syariah banks from 2010-2014. This study found that internal factors such as ROA, CAR, and financing margin were the factors that influence NPL, and the external factor was the growth of GDP and the exchange rate.

Ronny (2016) examined the analysis of the factors that affected the quality of credit at financing company PT. XYZ Finance. This study found that character, capacity, collateral, and capital parameters affected credit quality at financing company PT. XYZ Finance.

Rokhim \& Yanti (2014) examined NPL on Bank Pembangunan Daerah. This research used panel data from 2008-2011. The study found that the program with 20 percent loan growth target and 40 percent loan for productive financing increased NPL.

Usman, Kamaludin, \& Darmansyah (2015) conducted a study that aimed at identifying the determinants of Non-Performing Loan (NPL) in Indonesian banking sector. Data were collected from 16 banks with observation from 2002-2011. Further analysis was conducted using Pooled EGLS (cross-section random effects). The research results 
found that NPL were clearly driven by volatility and fluctuations in micro and macroeconomic factors. The factors consisted of Loan to Deposit Ratio (LDR), Capital Adequacy Ratio (CAR), Net Interest Margin (NIM), Inflation (INF), Interest Rate (IR), and exchange rate (ER) contributing to the variation of NPL in Indonesian banking sector.

Darussalam (2013) conducted research on the factors causing non-performing loans at PT Bank Sulut Manado main branch. The research result based on analysis extraction factor had obtained that the most dominant factor was the loan repayment period, the determination of bank interest rate, and the amount of credit received.

Andriani, Mezulianti, \& Hanum (2012) conducted a study on the level model of bank credit payment smoothness using ordinal logistic regression model (case study: Bank Rakyat Indonesia Tbk Bintuhan Market unit). Based on the results of the analysis and discussion, it could be concluded that the factors that affected positively on the provision of credit was the gender of men, age, loans, and collateral, and that negatively affected was the number of dependents in the family.

Samti (2011) conducted a research on the factors that affected the return of non-performing loans. This study concluded that the factors that had a significant effect on credit repayment were long occupancy of residence, other loan, and interest rate.

Limsombunchai, Gan, \& Lee (2005) investigated the profitability of financial institutions that provided agricultural credit in Thailand. This study found that the importance of loan to value on guaranteed assets, efficiency, and also the relationship between customers and banks. The higher the value of guaranteed assets and the more efficient the business activities of the customers were, the better the credit quality was. Conversely, the longer the customer relationship with the bank was, it had an inverse relationship to the credit quality.

\section{METHOD}

This study examined the effect of 4C (character, conditions, capital and capacity) on credit quality or NPL risk in used motorcycle financing in Indonesia. NPL was divided into 2 categories, namely: (1) customers having experienced delinquency overdue payment (delinquency or overdue) more than 90 days, and categorized as problematic customers; and (2) customers who had not experienced delinquency or overdue arrears for more than 90 days and categorized as smooth customers and in special attention.

There were totally 13 variables that were studied, and they were grouped into 4 categories namely: (1) character consisting of sex, age, length of stay, home ownership, marital status, and employment status; (2) capacity consisting of revenue and cost ratio with income; (3) collateral consisting of motorcycle brand and motor ownership; and (4) capital consisting of down payment and tenure (period) of financing.

This research was done by using logistic regression model because the dependent variable model in the model was dummy variable, by giving the value 0 for the customers who had the smooth or fluent category or in special attention and for the customers who had ever the delinquency more than 90 days or above the substandard/ less fluent category given value 1 . Logistic regression model is expressed as follows:

$$
\mathrm{Li}=\log \frac{P i}{1-P i}=b o+\sum_{j=1}^{k} \mathrm{~b}_{\mathrm{j}} \mathrm{x}_{\mathrm{ij}}
$$

\section{Information:}

$\mathrm{Li}$ : dependent variable (= 0 for "smooth" and "in-special attention" credit quality and $=1$ for "Non-performing", "doubtful", "stuck" category credit quality)

$\mathrm{Pi}$ : probability of credit quality

Xij : independent variable 


\section{Jurnal Keuangan dan Perbankan | PERBANKAN}

Vol. 21, No. 4, Oktober 2017: 650-658

From this model, it is obtained the prediction of credit quality as follows:

$$
\mathrm{Li}=\log \frac{P i}{1-P i}=b o+\mathrm{b}_{1} \mathrm{X}_{1}+\mathrm{b}_{2} \mathrm{X}_{2}+\ldots . .+\mathrm{b}_{13} \mathrm{X}_{13}+\mathrm{u}_{\mathrm{i}}
$$

Remarks:

$X_{1}$ : gender

$\mathrm{X}_{8}$ : expense ratio

$\mathrm{X}_{2}$ : marital status

$X_{9}:$ age

$\mathrm{X}_{3}$ : the length of stay

$\mathrm{X}_{10}$ : motorcycle brand

$X_{4}$ : status of residence

$X_{5}$ : occupation

$X_{11}$ : vehicle ownership

$X_{6}$ : length of work

$X_{12}$ : down payment

$X_{7}$ : income
2015 with the type of product that was used motorcycle financing with the total sample of 67,500 randomly selected customers.

In this study, the obligation of customer payments in the number of delinquent days to be the dependent variable, while the independent variables were gender, marital status, length of stay, home status, occupation, length of work, income, expenses, age, motor type, vehicle ownership, down payment, and tenure.

\section{RESULTS}

Descriptive Statistics of Character Parameters

From total of 67,500 customer samples, most of the samples were male customers with mean of 0.71 . With a mean of 0.80 , it indicated that more

Table 1. Operation of Research Variables

\begin{tabular}{|c|c|c|}
\hline Variables & Indicator & Scale \\
\hline \multicolumn{3}{|l|}{ Dependent Variables } \\
\hline \multirow[t]{2}{*}{ Credit Quality } & $0=<90$ days in arrears & Nominal \\
\hline & $1=>90$ days in arrears & \\
\hline \multicolumn{3}{|l|}{ Independent Variables } \\
\hline \multirow[t]{2}{*}{ Gender } & $0=$ Female & Nominal \\
\hline & 1 = Male & \\
\hline \multirow[t]{2}{*}{ Marital status } & $0=$ single $\&$ Widowed $/$ widower & Nominal \\
\hline & $1=$ married & \\
\hline Length of stay & Year of customers live at a location & Ratio \\
\hline \multirow[t]{2}{*}{ Home Ownership Status } & $0=$ House is not Contract & Nominal \\
\hline & $1=$ House of contract & \\
\hline \multirow[t]{2}{*}{ Occupation } & $0=$ Non-Entrepreneurs & Nominal \\
\hline & $1=$ Entrepreneur & \\
\hline Length of work & The individual year works on a business/ office & Ratio \\
\hline Income & $\begin{array}{l}\text { The ability of individual to earn money from his } \\
\text { work. Measured in revenue in one month }\end{array}$ & Ratio \\
\hline Expense Ratio & $\begin{array}{l}\text { Expense Ratio compared to revenue/ income with a } \\
\text { scale of } 0-1\end{array}$ & Ratio \\
\hline Age & $\begin{array}{l}\text { Individual age when entering a credit agreement } \\
\text { and using units of the year Productive age ranges } \\
\text { from 15-60 years }\end{array}$ & Ratio \\
\hline \multirow[t]{2}{*}{ Vehicle Brands } & $0=$ Non-Honda & Nominal \\
\hline & $1=$ Honda & \\
\hline \multirow[t]{2}{*}{ Vehicle Ownership } & $0=$ same as customer & Nominal \\
\hline & $1=$ different from customer & \\
\hline DP & DP uses unit 0 percent- 100 percent & Ratio \\
\hline Tenure & $\begin{array}{l}\text { The time length of the customer's payment until } \\
\text { fully paid for the proposed financing. }\end{array}$ & Ratio \\
\hline
\end{tabular}


than 50 percent of samples had marital status. The samples showed that they averagely lived at a location over 5 years with an average stay of 5 years and more. Home ownership had an almost equal number with those who did not have home yet with average of 0.45 . The number of entrepreneurs and non-entrepreneurs customers was almost balanced. The customers had averagely worked for almost 5 years. Occupation can be employees or entrepreneurs. The longest working was 6 years.
The average age of customers was at 37 years with the lowest age of 18 years and the oldest age of 59 years.

\section{Descriptive Statistics of Capacity Parameter}

The average customers earned IDR $5,000,000.00$ with the mean $\ln (15)$ in Table 2. The lowest earnings ranged from IDR 1,000,000.00. Average cost compared to income was 45 percent with the highest of 100 percent.

Table 2. Descriptive Statistics

\begin{tabular}{|c|c|c|c|c|c|}
\hline Variables & $\mathbf{N}$ & Minimum & Max & Mean & Std. Deviation \\
\hline Gender & 67,500 & 0.00 & 1.00 & 0.71 & 0.46 \\
\hline Marital status & 67,500 & 0.00 & 1.00 & 0.80 & 0.40 \\
\hline Length of stay & 67,500 & - & 6.00 & 5.35 & 1.32 \\
\hline Home Ownership Status & 67,500 & 0.00 & 1.00 & 0.45 & 0.50 \\
\hline Job status & 67,500 & 0.00 & 1.00 & 0.43 & 0.50 \\
\hline Length of work & 67,500 & 1.00 & 6.00 & 4.93 & 1.49 \\
\hline Income & 67,500 & 13.46 & 21.64 & 14.96 & 0.43 \\
\hline Revenue Cost Ratio & 67,500 & 0.00 & 6.00 & 0.45 & 0.15 \\
\hline Age & 67,500 & 18.00 & 59.00 & 36.49 & 9.19 \\
\hline Vehicle Brands & 67,500 & 0.00 & 1.00 & 0.53 & 0.50 \\
\hline BPKB Ownership & 67,500 & 0.00 & 1.00 & 0.51 & 0.50 \\
\hline Down payment & 67,500 & 25.00 & 94.00 & 43.15 & 10.23 \\
\hline Tenure & 67,500 & 6.00 & 30.00 & 6.94 & 4.81 \\
\hline Credit Quality & 67,500 & 0.00 & 1.00 & 0.13 & 0.34 \\
\hline Valid N & 67,500 & & & & \\
\hline
\end{tabular}

Table 3. Partial Test Results of Used Motorcycle Financing

\begin{tabular}{|c|c|c|c|}
\hline Variables & B & Prob. & Sig. \\
\hline Gender (JK) & -0.164 & 0.00 & $* *$ \\
\hline Marital Status (SP) & 0.107 & 0.00 & ** \\
\hline Length of Stay (LT) & 0.063 & 0.00 & $* *$ \\
\hline Home Ownership Status (SR) & -0.213 & 0.00 & $* *$ \\
\hline Type of Work (JP) & -0.033 & 0.00 & $* *$ \\
\hline length of Work (LB) & 0.050 & 0.00 & $* *$ \\
\hline Income $(\mathrm{P})$ & -0.052 & 0.70 & - \\
\hline Revenue Cost Ratio (ER) & -0.419 & 0.00 & $* *$ \\
\hline Age (U) & -0.012 & 0.00 & $* *$ \\
\hline Vehicle Brand (MK) & 0.339 & 0.00 & $* *$ \\
\hline BPKB Ownership (NB) & 0.277 & 0.00 & $* *$ \\
\hline Down Payment (DP) & 0.052 & 0.00 & $* *$ \\
\hline Tenure $(\mathrm{T})$ & -0.033 & 0.00 & $* *$ \\
\hline Constant & -1.823 & 0.00 & $* *$ \\
\hline
\end{tabular}

Description: ${ }^{* *}$ ) significant at the level $\pm=5$ percent 


\section{Descriptive Statistics of Collateral Parameter}

53 percent of customers had brand ownership of Honda. The majority of vehicles ownership with customers/ consumer financing was the same.

\section{Descriptive Statistics of Capital Parameters}

The average of customers' down payment was 43 percent and the highest was 94 percent. The average tenure of customers was 17 months with the longest for 30 months and the shortest for 6 months.

Based on Table 3, the logistic regression model is as follows:

$$
\begin{aligned}
\operatorname{Ln} \frac{p p}{1-p 1-p}= & -1.823-0.164 \mathrm{JK}+0.107 \mathrm{SP}+ \\
& 0.063 \mathrm{LT}-0.213 \mathrm{SR}-0.033 \mathrm{JP}+ \\
& 0.050 \mathrm{LB}-0.052 \mathrm{P}-0.419 \mathrm{ER}+ \\
& 0.012 \mathrm{U}+0.339 \mathrm{MK}+0.277 \mathrm{NB}+ \\
& 0.052 \mathrm{DP}-0.033 \mathrm{~T}
\end{aligned}
$$

\section{Testing Results of Logistic Regression Model}

This study used logistic regression to know partially the effect of each independent variable on the dependent variable. Test results using SPSS version 23.00 produced output in Table 3. Table 3 shows the significance values of all variables below $0.05(<0.05)$, except income, it shows that all variables other than income affect credit quality.

\section{DISCUSSIONS}

\section{Testing Results on Character}

For character parameters, 7 variables tested showed a significant effect on credit quality in which there were 4 variables showing negative influence and 3 variables showing positive influence.

Gender variables showed that female had a better credit quality risk compared with male. For marital status, married customers had better credit quality than single customers. Customers' ages also had a positive effect on credit quality. The older the customers were, the better the credit quality was. This was in line with the increasing responsibility of a consumer and age.

For home variable, length of stay had a positive influence on credit quality. The longer a customer domicile at a location showed the effect on better quality. This was also reflected by ownership having a positive effect on credit quality. A customer who had a home and a long stay had better credit quality.

For income variable, a customer working long time in a company had positive credit quality. The longer the consumer worked, the better the credit quality was. Non-entrepreneur consumers had a good influence on credit quality rather than entrepreneur customers. This research was in line with Sutanto \& Hamdani (2016) which showed the number of family, gender, and occupation affected NPL. Andriani, Mezulianti, \& Hanum (2012) showed that male, age, loan, and collateral affected the quality of banking credit. This study was also in line with Samti (2011) who concluded that the factors that significantly affected the credit repayment were the length of occupying residence.

So it could be concluded that customers who had low credit risk were the customers who were adult women, with steady jobs with the longer the better work, and the customers who lived in their own house and lived there longer.

\section{Testing Results on Capacity}

The income variable also showed an insignificant influence. The cost ratio compared to income showed a significant effect. The cost ratio was the amount of costs incurred on each income earned. The smaller the ratio of the income cost was, the higher the ability to pay the obligation was. 


\section{Testing Results on Collateral}

Collateral variable also indicated that collateral goods had to have the same data between customers of financing company and data of collateral goods as the name recorded at BPKB (proof of owner of motorized vehicle). In addition, motorcycles with the Honda brand had a better credit quality compared to other non Honda brands. Therefore, it could be concluded that the financing of Honda brand and requiring the names of consumers recorded had to be the same as the name of the customer had a better credit quality.

\section{Testing Results on Capital}

Down payment and tenure variables had the opposite characteristics. The bigger down payment made less credit risk. The customers who paid down payment maintained the credit quality and paid the installment on time compared to the customers with little down payment. Customers with short tenure had a better credit quality compared to those with long tenure. Thus, it could be concluded that a short tenor with a big down payment had a better credit quality. This study was in line with Darussalam (2013) research that stated the most dominant factor was the time range of credit payment and the amount of credit received. This research was generally in line with Ronny (2016) study which found that character, capacity, collateral, and capital parameters affected credit quality in financial institutions.

\section{CONCLUSION AND SUGGESTIONS}

\section{Conclusion}

Characters affect the credit quality of customer financing for purchasing two-wheeled motorcycle, especially for the variables of gender, marital status, age, occupation type, length of work, home ownership, and length of stay. Capacity also affects credit quality, especially for ex- pense ratio while income does not have a significant effect on the credit quality. Collateral affects credit quality, especially for vehicle brand and proof of ownership variables. Capital affects credit quality, especially for down payment and tenure variables.

\section{Suggestions}

Banking that wants to give credit needs to consider 4C namely character, capital, collateral, and capacity. The results show that $4 \mathrm{C}$ affect the quality of credit provision. Further research can add research variables such as adding collateral like property, machines, and other businesses. The next research can also add macroeconomic factors such as inflation conditions, types of customer industries and also types of businesses rather of the customers.

\section{REFERENCES}

Andriani, Y., Mezulianti, U., \& Hanum, H. (2012). Model tingkat kelancaran pembayaran kredit bank menggunakan model regresi logistik ordinal (Studi kasus: Bank Rakyat Indonesia Tbk unit Pasar Bintuhan). Jurnal Gradien, 8(2), 809-814.

Asosiasi Perusahaan Pembiayaan Indonesia. (2010). Modul training asosiasi perusahaan pembiayaan Indonesia.

Aryani, Y. (2016). Bank specific and macroeconomic determinants of non performing financing in islamic banking Indonesia. Tesis. Sekolah Pascasarjana Institut Pertanian Bogor.

Bank Indonesia. (2013). Surat edaran Bank Indonesia No. 15 tentang penilaian kualitas aset bank umum.

Bee, W. P., Ismail, N. H., \& Simon, F. (2011). Predicting car purchase intent using data mining approach. Eight international conference on fuzzy systems and knowledge management.

Blanco, A., Pino-Mejías, R., Lara, J., \& Rayo, S. (2013). Credit scoring models for the microfinance industry using neural networks: Evidence from Peru. Expert Systems with Applications, 40, 356-364. 


\section{Jurnal Keuangan dan Perbankan | PERBANKAN}

Vol. 21, No. 4, Oktober 2017: 650-658

Darussalam, O. (2013). Faktor-faktor penyebab kredit bermasalah di PT. Bank Sulut cabang utama Manado. Jurnal EMBA: Jurnal Riset Ekonomi, Manajemen, Bisnis, dan Akuntansi, 1(4), 69-77.

DeVaney S. A., \& Lytton, R. H. (1995). Household insolvency: A review of household debt repayment, delinquency, and bankruptcy. Financial Services Review, 4(2), 137-156.

Limsombunchai, V., Gan, C., \& Lee, M. (2005). An analysis of credit scoring for agricultural loans in Thailand. American Journal of Applied Science, 2(8), 11981205.

Menteri Keuangan. (2006). Peraturan Menteri Keuangan No. 84 tentang perusahaan pembiayaan.

Otoritas Jasa Keuangan. (2014a). Peraturan Otoritas Jasa Keuangan nomor 29/POJK.05/2014 tentang penyelengaraan usaha perusahaan pembiayaan.

Otoritas Jasa Keuangan. (2014b). Peraturan Otoritas Jasa Keuangan nomor 30/POJK.05/2014 tentang penyelengaraan usaha perusahaan pembiayaan.
Rokhim, R. \& Yanti, M. I. S. M. (2014). Risiko NPL kredit Bank Pembangunan Daerah sebagai regional champion. Jurnal Keuangan dan Perbankan, 18(1), 120-129.

Ronny, F. (2016). Analisis faktor-faktor yang mempengaruhi kualitas kredit pada perusahaan pembiayaan PT. XYZ Finance. Tesis. Universitas Tarumanagara.

Samti, A. M. (2011). Faktor-faktor yang mempengaruhi pengembalian kredit bermasalah oleh debitur gerai kredit verena Bogor. Skripsi. Fakultas Ekonomi dan Manajemen Institut Pertanian Bogor.

Sutanto, H. A., \& Hamdani, M. (2016). Determinan kredit perorangan (personal loan) (Studi kasus pada nasabah personal loan PT. Bank Jateng). Media Ekonomi dan Manajemen, 31(1), 69-76.

Usman, B., Kamaludin, K., \& Darmansyah. (2015). Determinan Non Performing Loan (NPL) pada industri perbankan (Bukti empiris perusahaan go publik di Bursa Efek Indonesia). Jurnal Aplikasi Manajemen (JAM), 13(4), 547-556. 